\title{
Kiai, Pesantren, dan Tantangan Masyarakat Multikultural
}

\section{Rijal Risalam Syamhuri}

\begin{abstract}
This article discusses the challenges of a multicultural Indonesian society where this diversity is vulnerable to friction and division. As for the reality, there are educational institutions that are able to stem this diversity into a strategy for the formation of human resources who are ready to face the challenges of globalization that know no national borders. Pesantren is a heterogeneous environment in which students come from various races, cultures, social strata of society, economic backgrounds with various individual characters. The kiai, as role models and central figures in the pesantren, need to first turn on the multicultural values in them, which then together with all pesantren residents live the multicultural values in the pesantren. The kiai's example becomes a strategic educational method in forming students who are critical and open to progress and can participate in forming a society that thinks positively about diversity.
\end{abstract}

Keywords: Kiai, pondok pesantren, multicultural society

\section{Pendahuluan}

Indonesia merupakan negara yang luas yang secara geografis memiliki lebih dari 17.500 pulau besar dan kecil, terbentang dari Sabang sampai Merauke. Luas wilayah tersebut membawa Indonesia pada keanekaragaman kultur, baik secara horizontal yang meliputi perbedaan sosial seperti suku, bangsa, bahasa, adat istiadat, agama, maupun secara vertikal yang meliputi perbedaan lapisan atas dan bawah, sosial, politik, ekonomi, maupun budaya. Untuk itulah, warga negara Indonesia sangat rentan terhadap kesalahpahaman dan perpecahan disebabkan beragamnya kebudayaan.

Keberagaman merupakan sunnatullah yang menggambarkan keagungan Allah SWT yang menjadikan bumi ini dan segala isinya berbeda satu dengan yang lainnya. Allah SWT menghendaki keberagaman ini sebagai sarana untuk saling memahami dan mengenal yang kemudian diharapkan mampu secara bersama-sama untuk memelihara bumi dan menjaganya. Sebagaimana firman Allah SWT: Hai manusia, Sesungguhnya Kami menciptakan kamu dari seorang laki-laki dan seorang perempuan dan menjadikan kamu berbangsa - bangsa dan bersuku-suku supaya kamu saling kenal-mengenal. Sesungguhnya orang yang 
paling mulia diantara kamu disisi Allah ialah orang yang paling taqwa diantara kamu. Sesungguhnya Allah Maha mengetahui lagi Maha Mengenal.

Shihab (2005) mengemukakan bahwa ayat ini menegaskan tentang kesatuan asal usul manusia dengan menunjukkan kesamaan derajat kemanusiaan manusia. Tidak wajar seseorang berbangga dan merasa diri lebih tinggi daripada yang lain, bukan saja antara satu bangsa, suku, atau warna kulit dan selainnya, tetapi antara jenis kelamin mereka. Allah SWT memerintahkan untuk menjadikan perbedaan tersebut sebagai sarana untuk saling mengenal, semakin kuat pengenalan satu pihak kepada pihak lainnya, semakin terbuka pula peluang untuk saling memberi manfaat. Untuk itu, ayat di atas menekankan perlunya saling mengenal. Perkenalan itu dibutuhkan sebagai sarana untuk saling menarik pelajaran dan pengalaman pihak lain guna meningkatkan ketakwaan kepada Allah SWT. yang berdampak pada kedamaian dan kesejahteraan hidup duniawi dan ukhrawi. (Shihab, 2005)

Manusia yang baik dan istimewa adalah yang memiliki akhlak yang baik terhadap Allah dan terhadap sesama makhluk. Banyak diantara manusia yang mengira bahwa materi, kecantikan, serta kedudukan sosial karena kekuasaan atau keturunan adalah kemuliaan yang penting dimiliki. Padahal, keistimewaan dan sumber kemuliaan tersebut bersifat sementara bahkan terkadang mengantar pemiliknya kepada kebinasaan. Kemuliaan adalah sesuatu yang langgeng sekaligus membahagiakan. Kemuliaan yang abadi dan langgeng adalah di sisi Allah SWT. dan untuk menggapai kemuliaan itu dengan mendekatkan diri kepada-Nya, menjauhi larangan-Nya, melaksanakan perintah-Nya dan meneladani sifat-sifatnya sesuai kemampuan manusia, itulah takwa. Demikianlah, yang paling mulia di sisi Allah adalah yang paling bertakwa. (Shihab, 2005)

Penutup ayat ini menjelaskan bahwa kualitas ketakwaan dan kemuliaan seseorang di sisi Allah Merupakan sesuatu yang sangat sulit, bahkan mustahil, seorang manusia dapat menilai kadar dan kualitas keimanan serta ketakwaan seseorang, yang mengetahuinya hanya Allah SWT. untuk itulah, apa yang ditetapkan Allah menyangkut esensi kemuliaan adalah yang paling tepat, bukan apa yang diperebutkan oleh banyak manusia karena Allah Maha Mengetahui dan Maha Mengenal. (Shihab, 2005)

Kita memahami bahwa keberagaman merupakan dua mata pisau yangmana dapat menjadi suatu kekayaan budaya namun di sisi lainnya dapat menjadi ancaman terhadap kedamaian di suatu negara. Hal ini perlu menjadi perhatian pemerintah sebagai pemegang kekuasaan agar dapat menjadi figur dan penengah apabila terjadi hal-hal yang mengarah kepada perpecahan, kemudian bersama-sama dengan seluruh masyarakat membangun suatu sikap yang mengedepankan kepentingan bersama guna meminimalisir terjadinya perpecahan.

Selanjutnya, arus globalisasi dan perkembangan zaman yang semakin pesat menyebabkan kemajemukan yang lebih besar hingga mencakup ranah 
internasional. Perolehan informasi, pencampuran budaya tanpa mengenal batas wilayah. Hal ini pun perlu menjadi perhatian disebabkan apabila Indonesia tidak mempersiapkan diri terhadap arus globalisasi yang kian hari semakin cepat maka akan tertinggal. Untuk itulah, perlu membentuk sumber daya manusia yang unggul yang dapat bersaing diranah global.

Pendidikan menjadi suatu kebutuhan manusia agar dapat bertahan hidup. Begitupula, permasalahan di atas dapat diminimalisir melalui pendidikan. Pendidikan yang berfokus kepada pengembangan potensi peserta didik merupakan kebutuhan yang urgen untuk menghadapi masalah tersebut karena memberikan kesempatan kepada peserta didik untuk berkembang sesuai potensinya dan kita memahami bahwa potensi peserta didik itu beragam dan sangat kompleks. Begitupula, melalui pendidikan diharapkan peserta didik mampu menjadi bagian dari masyarakat multikultural yang senantiasa menghormati dan menghargai satu dengan lainnya, bukan sebaliknya sebagai generasi yang mengundang perpecahan.

Atas dasar itulah, pendidikan di Indonesia seyogyanya sudah menerapkan nilai-nilai pendidikan multikultural di berbagai jenjang pendidikan. Komponen pendidikannya pun perlu didesain berdasarkan niali-nilai multikulturalis terutama para pemangku pendidikan yang bersinggungan langsung dengan peserta didik.

Multikultural merupakan suatu sikap menerima dan terbuka terhadap perbedaan. Pendidikan multikultural banyak diwacanakan sebagai salah satu treatment untuk menanamkan sikap toleransi pada individu sejak dini. Pendidikan bukan bersifat memindahkan pengetahuan saja (transfer of knowlage) namun pendidikan memiliki makna yang mendalam yakni sebagai proses transfer sikap atau nilai (transfer of values). (Zamani, 2019)

Nilai-nilai multikultural bisa diwujudkan dimanapun dan kapanpun, seperti di lingkungan sekolah, lingkungan keluarga, lingkungan masyarakat dan lingkungan pesantren. Pesantren merupakan lingkungan pendidikan yang strategis dalam mengimplementasikan nilai-nilai multikultural, yakni dengan mengamalkan sikap saling menyayangi, menghargai, menghormati kepada beragam individu disetiap saat.

Lembaga pendidikan pesantren merupakan salah satu lembaga pendidikan yang sudah menerapkan nilai-nilai pendidikan multikultural dilihat dari sudut pandang santrinya yang notabene merupakan perantauan dari berbagai daerah. Kita memahami bahwa Indonesia merupakan negara yang memiliki keberagaman yang sangat kompleks dari berbagai sudutnya, namun pesantren dapat menjadi tempat yang strategis dalam menerima keberagaman tersebut. Belum kita dapati bahwa di dalam pesantren ada kasus tawuran, genjatan senjata, bentrokan dan sebagainya. Adapun jika kita amati dari segi keberagaman santri, rentan adanya gesekan dan berpotensi terjadinya perpecahan, namun dalam kenyataannya pesantren dapat membendung itu semua. 
Pesantren memiliki lingkungan yang heterogen, di mana seluruh santri yang berada dipesantren datang dari barbagai perbedaan ras, budaya, lapisan sosial masyarakat, bahkan dengan karakter individu yang beragam. Begitu pula dengan pola hidup di pesantren yang mengedepankan pembentukan dan penerapan nilai-nilai agama untuk saling menolong, toleransi, saling menghormati dan saling berbagi. Hal tersebut senada dengan makna masyarakat multikultural adalah suatu masyarakat yang mempunyai banyak struktur kebudayaan disebabkan oleh banyaknya suku bangsa yang memiliki struktur budaya sendiri. (Suheri \& Nurrahmawati, 2018)

Senada dengan pendapat di atas, Zamani (2019) mengemukakan bahwa pondok pesantren adalah lembaga pendidikan islam yang dilaksanakan dengan sistem asrama dan kiai sebagai pusat utama pelaksanaan pembelajaran, serta masjid sebagai pusat terselengaranya kegiatan pembelajaran. Awal berdirinya pesantren bermula dari masjid, para santri tinggal menyebar di desa-desa, dan saat tiba waktu mengaji bersama kiai para santri berdatangan untuk mengikutinya. (Zamani, 2019)

Adapun dalam perkembangannya muncul stigma bahwa pesantren adalah the breeding ground, tempat berkembangbiaknya radikalisme dan terorisme. Hal ini dilatarbelakangi oleh kasus bom bali yang disinyalir pelaku pengeboman adalah jebolan pesantren, namun bukan hal yang bijak jika kita mengeneralisasi bahwa jebolan pesantren terindikasi sebagai teroris, karena apabila kita amati bahwa pesantren di Indonesia besar menganut paham fiqh tawazun (menjaga keseimbangan dan harmoni), tasammuh (toleransi) dan tasyawwur (musyawarah) yang selalu berupaya menampilkan sikap akomodatif yang seimbang dengan budaya setempat.

Atas dasar hal itulah, penting kiranya bagi para pengasuh pesantren terutama sang kiai sebagai figur sentral di pesantren harus mencerminkan sosok yang menghidupkan nilai-nilai multikulturalis, supaya nilai-nilai tersebut dapat dicontoh oleh para santri yangmana keteladanan merupakan metode pendidikan yang strategis dalam pembentukan karakter santri terutama dalam menghadapi era globalisasi yang meniscayakan adanya kemajemukan secara internasional.

Berdasarkan deskripsi di atas, peneliti merasa perlu untuk menganalisis tentang tangtangan masyarakat Indonesia yang multikultural yangmana cerminan masyarakat tersebut sudah terealisasikan di lingkungan pesantren. Untuk itulah, peneliti tertarik untuk mendalami persoalan tersebut yang tertuang dalam judul penelitian "kiai, pesantren dan tantangan masyarakat multikultural"

\section{METODE}

Penelitian ini menggunakan jenis penelitian kualitatif deskriptif. Sujarweni (2014:20) menjelaskan bahwa penelitian kualitatif merupakan salah satu 
prosedur penelitian yang menghasilkan data deskriptif berupa ucapan atau tulisan. (Sujarweni, 2014)

Adapun metode penelitian yang digunakan adalah studi pustaka atau library research. Mukhtar (2013: 10) menjelaskan studi pustaka yaitu menelusuri karya-karya besar yang dihasilkan oleh para pakar secara monumental atau menelusuri buku-buku teks yang digunakan dalam pembelajaran atau berbagai penelitian ilmiah. Sumber data primer dalam penelitian ini adalah berbagai penelitian ilmiah yang berkaitan dengan konsep multikultural di pesantren. Sedangkan sumber data sekunder berupa buku teks yang berkaitan dengan konsep multikultural di pesantren. (Mukhtar, 2013)

Teknik dan instrumen pengumpulan data yang digunakan dalam penelitian ini adalah studi dokumentasi. Studi dokumentasi dilakukan dengan langkah sebagai berikut; 1) menghimpun sumber data yang berkaitan dengan konsep multikultural, 2) memahami dan menganalisis sumber data yang berkaitan dengan judul penelitian, 3) menarik kesimpulan dan mendeskripsikan tentang konsep masyarakat multikultural serta kaitannya dengan kiai dan pesantren.

\section{HASIL DAN PEMBAHASAN}

Multikultural memiliki makna keberagaman budaya. Multikutural berasal dari dua suku kata, multi artinya banyak atau beragam dan kultural budaya atau kebudayaan. Dalam buku multikultikuturalisme, multikultural dipahami sebagai bentuk sikap multikulturalisme atau sikap terbuka atas perbedaan.

Multikulturalisme merupakan sebuah gagasan yang dicetuskan serta dikembangkan dalam sebuah konteks dalam melihat realitas keragaman sosial masyarakat. Dalam era modern dengan ditandai semakin meningkatnya proses terjadinya perpindahan penduduk atau migrasi yang diiringi pertukaran sebuah kebiasaan dan budaya masyarakat Indonesia yang berbeda-beda semakin mengasah konsep multikulturalisme. Hal ini, konsep multikulturalisme mempererat dan menuntut dalam interaksi sosial untuk dapat memahami, menghargai, serta mengakui latar belakang asasi dalam mewujudkan sebuah keadilan sosial bagi semuanya dengan tujuan untuk memupuk sebuah cita-cita idealis yang ingin dicapai oleh multikulturalisme. Multikulturalisme dalam penerapannya dalam kehidupan berkaitan era sekali dengan sebuah kebijakan dan peraturan negara terhadap realitas dalam perbedaan utamanya kaum minoritas. (Fakih, 2017)

Pendidikan multicultural (multicultural education) di perlukan sebagai sebuah merupakan sebuah respon terhadap perkembangan keragaman dan perbedaan populasi di lingkungan sekolah, adanya tuntutan persamaan hak bagi setiap grouf. Dalam dimensi lain, pendidikan dalam multicultural adalah sebuah pengembang didalam kurikulum dan aktivitas pendidikan dengan tujuan untuk memasuki berbagai pandangan, sejarah, prestasi, dan perhatian untuk terhadap orang-orang non eropa (Hilliard, 1991-1992). 
Orientasi didalam pendidikan multikultural yaitu mengembangkan kompetensi dan kapasitas santri secara maksimal sesuai kodratnya yang merupakan given dari Allah SWT. Pendidikan multikultural adalah suatu pendekatan progresif untuk melakukan transformasi pendidikan yang secara menyeluruh membongkar kekurangan, kegagalan, dan praktik-praktik diskriminasi dalam proses pendidikan (Baharun \& Awwaliyah, 2017).

1. Sikap yang mencerminkan nilai multikultural

a. demokrasi (al musyawarah),

Al-musyawarah memiliki arti musyawara, pertimbangan, dan nasehat, musyawarah merupakan landasan dalam berinteraksi bukan saja dalam lingkup politik tetapi musyawarah juga digunakan sebagai metode interaksi sosial untuk menghasilkan suatu keputusan bersama. Musyawarah adalah bentuk dari kedewasaan diri dalam menyelesaikan masalah, karena dalam bermusyawarah kita dapat menghargai pendapat orang lain dan mengurangi ego. Hal ini digambarkan dalam firman Allah SWT : Dan (bagi) orang-orang yang menerima (mematuhi) seruan Tuhannya dan mendirikan shalat, sedang urusan mereka (diputuskan) dengan musyawarat antara mereka; dan mereka menafkahkan sebagian dari rezki yang Kami berikan kepada mereka. (QS. AsySyuraa [42]: 38)

b. kesetaraan (al musawwah),

Al-musawwah berarti kesetaraan, bahwasannya manusia adalah bersaudara berasal dari satu ciptaan dan dan setara dihadapan Pencipta, meski memiliki keragaman perbedaan dan kepercayaan. Hal ini digambarkan dalam firman Allah SWT: Hai manusia, Sesungguhnya Kami menciptakan kamu dari seorang laki-laki dan seorang perempuan dan menjadikan kamu berbangsa bangsa dan bersuku-suku supaya kamu saling kenal-mengenal. Sesungguhnya orang yang paling mulia diantara kamu disisi Allah ialah orang yang paling taqwa diantara kamu. Sesungguhnya Allah Maha mengetahui lagi Maha Mengenal. (QS. Al-Hujurat [49]: 13)

c. adil (al adl).

Perilaku adil merupakan sikap dalam memandang sama pada setiap orang, memperlakukan orang lain sebagaimana kita ingin diperlakukan dan seimbang antara hak dan kewajiban serta tidak memihak. Sesungguhnya Allah menyuruh (kamu) Berlaku adil dan berbuat kebajikan, memberi kepada kaum kerabat, dan Allah melarang dari perbuatan keji, kemungkaran dan permusuhan. Dia memberi pengajaran kepadamu agar kamu dapat mengambil pelajaran. (QS. An-Nahl [16]: 90)

\section{Konsep Kiai}

Istilah kiai dalam bahasa jawa mempunyai pengertian yang luas. Ia berarti mencirikan benda maupun manusia yang diukur dalam sifat-sifatnya yang istimewa, sehingga sangat di hormati. Misalnya dikatakan sakti bila sang empu mampu memasukkan kesaktian pada keris buatannya. Keris-keris semacam itu 
dijuluki atau diberi predikat kiai (Zamakhsyari, 2011: 55). Senjata dan bendabenda keramat yang memiliki kekuatan ghaib ini selalu dipuja dan diwarisi sebagai sumber kekuatan gaib atau pusaka. Kadar semantik dari istilah kiai di sini mencakup komponen tradisional jawa secara mutlak, termasuk pimpinan pesantren.

Adapun dalam kontek bermasyarakat, kiai merupakan seseorang yang dijadikan sebagai figur yang dihormati dan disucikan oleh masyarakat karena dianggap sebagai lambang kewahyuan ilahi. Fatwa-fatwa kiai dianggap memiliki keramat dan kebenarannya tidak diragukan sehingga tidak boleh dikritik ataupun disangkal.

Pengertian kiai dalam konteks Indonesia modern telah mengalami transformasi makna yaitu diberikan kepada pendiri dan pimpinan pondok pesantren yang membaktikan hidupnya demi Allah SWT dan demi kemajuan pesantren serta menyebarluaskan dan memperdalam ajaran-ajaran Islam melalui kegiatan pendidikan. Untuk itulah, maka predikat kiai senantiasa berkenaan dengan suatu gelar yangmenimbulkan penekanan kemuliaan dan pengakuan yang diberikan secara sukarela kepada ulama dan pemimpin masyarakat setempat sebagai sebuah tanda kehormatan bagi kehidupan sosial dan bukan merupakan suatu gelar akademik yang diperoleh melalui pendidikan formal. (Rosita, 2018)

Karakteristik Islam yang ditampilkan oleh para ulama pemangku pesantren sebagaimana Nabi SAW mengajarkannya adalah penanaman dan pengembangan nilai-nilai infitah (inklusif), tawassut (moderat), musawah (persamaan), dan tawazun ( seimbang). Karena itu maka pesantren tampil pula sebagai agen pembudayaan nilai, norma, sekaligus pesan-pesan keagamaan yang memiliki nilai harmoni, kerukunan, persatuan, dan kedamaian bahkan para ahli menilai pesantren mempunyai peran yang cukup signifikan dalam melestarikan budaya lokal, termasuk memelihara nilai-nilai dan tatanan sosial yang harmonis di sekelilingnya.

Kiai, dikaitkan dengan pesantren merupakan pimpinan di lembaga pendidikan pondok pesantren. Model kepemimpinan kiai di suatu lemabaga pendidikan berbeda antara satu pesantren dengan pesantren lainnya. Seorang kiai ada yang menggunakan model kepemimpinan one man show dan ada pula yang menggunakan model kepemimpinan power sharing.

1. Kepemimpinan Kiai

Kepemimpinan adalah suatu kemampuan seseorang dalam memimpin, yaitu kemampuan dalam memengaruhi anggotanya/ orang lain untuk bertindak sesuai dengan apa yang ia inginkan, sehingga anggota tersebut bekerja dengan suka rela. Sebagaimana Rosita (2018) mengemukakan bahwa kepemimpinan (leadership) merupakan kemampuan seseorang (pemimpinan atau leader) untuk mempengaruhi orang lain, sehingga orang tersebut bertingkah laku sesuai dengan yang dikehendaki oleh sang pemimpin. Pengaruh tersebut digunakan oleh pimpinan sebagai satu cara mencapai tujuan 
yang telah ditetapkan. Sumber pengaruh yang dimiliki oleh seorang pemimpin bisa didapat secara formal maupun secara informal. (Rosita, 2018)

Sumber formal diperoleh apabila sang pemimpin berada pada posisi atau jabatan rtentu dalam suatu kelompok, memilki dasar legalitas, diangkat secara resmi serta memiliki hak dan kewajiban yang tegas sesuai dengan jabatannya, seperti Presiden, ketua umum suatu partai dan direktur sebuah perusahaan. (Rosita, 2018)

Adapun sumber informal (tidak resmi) diperoleh melalui organisasi atau kelompok masyarakat yang tidak formal serta tidak tergantung pada acuan formal legitimasi. Sumber kepemimpinan ini sangat tergantung pada pengakuan suatu kelompok dan komunitasnya, sehingga pemimpin perlu memiliki kualitas yang benar-benar unggul, seperti pemuka agama, tokoh masyarakat dan tokoh adat. (Rosita, 2018)

2. Kiai sebagai figur sentral di pesantren

Kiai merupakan pendiri dan pimpinan pondok pesantren yang membaktikan hidupnya demi Allah SWT dan demi kemajuan pesantren serta menyebarluaskan dan memperdalam ajaran-ajaran Islam melalui kegiatan pendidikan. Kiai sebagai tokoh sentral di pesantren dijadikan sebagai figur yang dihormati dan disucikan oleh masyarakat maupun santri karena dianggap sebagai lambang kewahyuan ilahi. Fatwa-fatwa kiai dianggap memiliki keramat dan kebenarannya tidak diragukan sehingga tidak boleh dikritik ataupun disangkal. Untuk itulah, keteladanan dari kiai menjadi metode yang strategis dalam penanaman akhlakul karimah di pesantren.

Keteladanan merupakan suatu sikap yang dicerminkan oleh seseorang baik disengaja ditampakkan untuk dijadikan figur oleh orang lain maupun perilaku baik yang ditimbulkan tanpa sengaja karena telah menjadi kebiasaan. Untuk itu, dalam menanamkan karakter pada anak sangat dibutuhkan sosok figur yang dapat ditemukan oleh peserta didik di lingkungan sekitarnya. (Iswandi, 2019)

Pendekatan keteladanan menjadi pola pendidikan yang kerap kali disinggung dalam al-Qur'an dan al-Hadits maupun dalam teori pendidikan yang memiliki peran besar dalam membentuk karakter santri/ peserta didik. Santri sebagai miniatur orang dewasa melihat apa yang diperbuat dan mendengar apa yang diucapkan oleh para kiai. Sikap hati-hati dan kesadaran diri para kiai maupun pengasuh pesantren akan pentingnya keteladanan ini harus berbanding lurus dengan pengetahuan tentang fase-fase perkembangan santri, sehingga bimbingan dan arahan yang dilakukan oleh kiai maupun pengasuh pesantren dapat mewujudkan karakter yang diharapkan. Sebuah pepatah mengatakan "seorang anak tidak pandai mendengar, namun ia pandai meniru".

Yusuf (2019) mengemukakan bahwa keteladanan yang diimplementasikan di pesantren dapat di ketegorikan menjadi tiga macam, yaitu; Pertama, multikultural kognitif, yaitu keteladanan kiai berupa pemikiran, gagasan, 
prinsip, paradigma atau ide, mind set, pola pikir kiai tentang wawasan dan pemahaman terhadap nilai-nilai pendidikan multikultural.

Kedua, multikultural afektif, yaitu keteladanan kiai melalui gaya atau makna yang menunjukkan perasaan kiai tentang pernyataan yang bermuatan nilai-nilai pendidikan multikultural. Hal ini dibuktikan dengan adanya pesan atau nasehat kepada santri pada saat pengajian baik melalui cerita-cerita atau kisah-kisah kaum yang sukses atau tidak sukses atau cerita para ulama terdahulu dengan harapan santri memiliki antusias dan termotivasi dalam mengimplementasikan pendidikan multicultural. (Yusuf, 2019)

Ketiga, multikultural psikomotorik yaitu keteladanan kiai yang dicontohkan kepada santri melalui aktivitas, sikap, dan kegiatan secara langsung disaksikan oleh santri atau jamaah yang berkaitan dengan wawasan multikultural. (Yusuf, 2019)

Konsep Pesantren

Pesantren merupakan lembaga pendidikan tertua di Indonesia. Lingkungan pesantren merupakan suatu lingkungan yang heterogen karena santri yang datang adalah perantauan dari bergbagai daerah. Sebagaimana Zamani (2019) mengemukakan bahwa Pesantren memiliki lingkungan yang heterogen, di mana seluruh santri yang berada dipesantren datang dari barbagai perbedaan ras, budaya, lapisan sosial masyarakat, bahkan dengan karakter individu yang beragam. Begitu pula dengan pola hidup di pesantren yang mengedepankan penanaman dan penerapan nilai-nilai agama saling menolong, toleransi, saling menghormati, saling berbagi. Hal tersebut senada dengan makna masyarakat multikultural adalah suatu masyarakat yang mempunyai banyak struktur kebudayaan disebabkan oleh banyaknya suku bangsa yang memiliki struktur budaya sendiri dan berbeda dengan budaya suku lainnya. (Zamani, 2019)

Pada umumnya kiai yang menjadi pemimpinnya sebagai penggerak kehidupan yang ada di dalamnya, kiai akan menugaskan para santri senior untuk menjadi pengurus yang mengatur segala kebutuhan seluruh santri junior (adik kelasnya), dalam budaya pesantren tradisional (salaf) mereka dipanggil sebagai "lurah pondok". Para santri akan dipisahkan dari orang tua mereka dan keluarga mereka dengan tujuan untuk melahirkan dan menumbuhkan kemandirian pribadi dari para santri sehingga terjadi peningkatan dalam hubungan mereka dengan kiai dan juga Allah Swt. serta hidup penuh dengan kesederhanaan. Ciri-ciri pondok pesantren antara lain: 1) Asrama (pondok) sebagai tempat mereka menginap, 2) Peserta didik di pondok pesantren dinamakan dengan istilah 'santri', 3) Sarana peribadahan dan sentral pembelajaran dilakukan khusus di masjid pesantren, 4) Kiai sebagai murabby yang menjadi sosok utama ulama yang ahli dalam ilmu agama Islam, berkharisma tinggi selalu disegani oleh para santri, bahkan menjadi figur contoh bagi para santrinya, 5) Kitab gundul atau kitab kuning yang dijadikan referensi utama untuk mengkaji berbagai keilmuan agama Islam, baik fan mahwu, fan fiqih, fan tauhid dan fan ilmu-ilmu lainnya. (Dhofier, 2011) 
Pondok pesantren pertama kali hadir dengan menggunakan sistem pembelajaran yang bersifat nonklasikal, yang menjadi pengajar agama Islamnya ialah seorang kiai, hal ini telah tertulis sejak abad pertengahan. Walaupun kajian-kajian keilmuan di dalamnya pada umumnya mengupas tuntas segala permasalahan tentang tafsir al-Qur'an, fikih, bahasa Arab dan berbagai ilmu agama dibedah di dalamnya. Di Indonesia khususnya banyak mengkaji fikih yang berdasarkan madzhab Imam Syafi'I, sedangkan madzhab yang lain sedikit dikaji dan bukan berarti tidak dikaji seperti kitab Hidayatul Mustafid karangan Ibnu Rusyd yang membahas fikih perbandingan empat imam madzhab yakni Imam Maliki, Imam Syafi'I, Imam Hambali dan Imam Hanafi. Adapun kajian akhlak dan tasawuf mengambil referensi dari berbagai kitab kuning karangan Imam al-Ghazali yang diwarnai oleh beberapa tokoh ahli sufi lainnya juga sehingga tidak hanya terfokus pada satu tokoh ahli. Azra mengatakan bahwa pesantren hanya sedikit menelaah fan tasawuf dengan kajian yang mendalam, yang para santri kaji hanya beberapa dasar tasawuf pemikiran dari imam al-Ghazali dan asy-'Ariyyah. (Azyumardi, 2001)

Adapun dalam realitasnya saat ini, pesantren mulai mengakomodir tuntutan perubahan sosial, serta mulai melakukan transformasi menjadi lembaga pendidikan modern dengan mengadopsi kurikulum pemerintah dan kurikulum yang dikembangkan lembaga pendidikan umum. Untuk itulah, beberapa pesantren mengintegrasikan kurikulum yang berasal dari pemerintah dan kurikulum yang murni dari pesantren dengan tujuan untuk membekali santrinya tidak hanya tafaqquh fi al-din tetapi juga memiliki kemampuan atas ilmu umum. Begitupula pula, implementasi nilai-nilai Islam tidak hanya dibangun di atas teks kitab suci Al-Qur'an dan Hadits, melainkan aktualisasikannya memerlukan dialektika panjang antara teks suci yang bersumber dari wahyu dan cenderung otoritatif dengan kultur tradisi masyarakat Indonesia yang lebih bersifat lokalistik bahkan mengadopsi budaya leluhur. Atas dasar itulah, penting untuk mempelajari dan mendalami hasil "kompromi" antara teks dan konteks dalam Islam ala Indonesia. Sebab, perkembangan Islam di bumi nusantara ini sangat dinamis dan progresif. Meskipun sekilas tampak tidak ada perubahan, namun bila diamati secara detail interpretasi terhadap nilai-nilai Islam cenderung dinamis. (Fauzi, 2017)

1. Fungsi Pesantren

Pesantren memiliki fungsi tertentu tidaklah hanya dijadikan lembaga pendidikan agama saja, tetapi pesantren teleh bertransformasi secara komplek karena itu adalah tugas pesantren. Pembelajaran di pesantren tidahlah hanya dalam transfer keilmuan saja tetapi berbagai kegiatan pembelajaran untuk mengembangkan potensi para santri semuanya dilaksanakan di dalam pesantren. Hal ini seperti yang dikemukakan oleh mantan menteri agama Indonesia Tholkhah Hasan bahwa pesantren harus mampu menghidupkan berbagai fungsinya, yakni: 1) nilai-nilai agama Islam dan ilmu-ilmu agama Islam harus pesantren transfer kepada seluruh santrinya, 2) kontrol sosial harus 
mampu pesantren lakukan, bahkan disamping itu pesantren juga harus mampu sebagai lembaga penggerak umat, dan 3) rekayasa dan perkembangan masyarakat harus mampu dilakukan oleh pesantren. Hal ini semua menurut Hasan dapat dilaksanakan oleh pesantren jika mereka mampu mempertahankan tradisi-tradisi yang positif dan tetap juga harus mampu menyesuaikan terhadap berkembangnya berbagai ilmu-ilmu baru yang lebih baik mereka adopsi dan kembangkan di dalam pesantren, sehingga pesantren menjadi alah satu agen perubahan umat (agent of change) (Wahidah, 2015: 184-207).

\section{Internalisasi nilai-nilai multikultural di pesantren}

Pondok pesantren merupakan lembaga pendidikan yang telah mengimplementasikan nilai-nilai multikultural dalam kesehariannya, nilainilai tersebut antara lain:

a. Nilai kesetaraan

Nilai kesetaraan dapat kita temukan pada kegiatan-kegiatan di bawah ini:

1) Penerimaan santri

Penerimaan santri yang akan belajar di pesantren, diterima dari berbagai latar belakang yang beragam, suku, bahasa, ras, status sosial. Pihak pesantren tidak memandang status sosial para santri yang mendaftar, namun ada beberapa pesantren yang menerapkan pretest seperti pretst membaca al-Qur'an untuk menyeleksi calon santri yang akan mendapat tambahan bimbingan atau tidak mendapat tambahan bimbingan.

2) Pembagian kamar

Santri baru atau santri lama dalam penempatan kamar asrama tidak ada perbedaan, baik santri itu berasal dari desa maupun kota, anak pejabat ataupun anak petani semuanya menempati kamar dan mendapatkan fasilitas yang sama, karena yang membedakan hanyalah ketaqwaannya.

3) Forum diskusi

Pembahasan dalam diskusi ini bertujuan agar santri memiliki sikap yang luwas dan luwes dalam menghadapi permasalahan yang ada di masyarakat. Hal ini sesuai dengan pendapat Muhaimin bahwa strategi yang digunakan dalam penanaman nilai adalah moral reasoning. Moral reasoning adalah penerapan diskusi yang dilakukan dengan adanya penyajian dilema hukum atau persoalan-persoalan yang bersifat kontradiktif, kemudian masalah tersebut didiskusikan dengan beberapa mengasilkan pemahaman yang utuh.

4) Melibatkan santri

Santri dilibatkan secara aktif pada program-program internal maupun program-program eksternal pesantren. Program internal pesantren meliputi aktivitas rutinan harian, mingguan, bulanan atau tahunan yang diselenggarakan oleh pesantren, seperti pengajian kitab kuning di asrama, baik dengan system sorogan maupun bandongan. Adapun program ekternal pesantren yang bersinggungan dengan masyarakata atau dengan non muslim. 
Berdasarkan deskripsi di atas, dapat kita ketahui bahwa pesantren bukanlah suatu tempat untuk mengembangbiakkan paham-paham radikalisme, namun sebaliknya, di lingkungan pesantren terdapat banyak nilai-nilai multikultural yang tergambar dalam keseharian para pengasuh pesantren maupun para santinya. Untuk itulah, tidaklah bijak kiranya jika kita mengeneralisasi dan menjastifikasi bahwa pesantren adalah sarana untuk membentuk para teroris disebabkan oleh beberapa pelaku teroris adalah jebolah pesantren. Seharusnya, masyarakat lebih mendalami dan menganalisis bahwa pemahaman seseorang dipengaruhi oleh banyak faktor, baik buku bacaan, teman bergaul, dan sebagainya.

\section{KESIMPULAN}

Multikultural seolah-olah menjadi dua mata pisau bagi masyarakat Indonesia, karena masyarakat yang multikultural dapat menjadi suatu kekayaan budaya dan dapat pula menjadi sumber perpecahan bagi masyarakat. Penting bagi seluruh warga negara Indonesia baik di ranah pemerintahan maupun di ranah masyarakat untuk bersama-sama membangun Indonesia yang memandang kemajemukan sebagai sunnatullah, rahmah, sarana untuk saling mengenal dan sarana untuk dapat berkembang bersama-sama. Nilai-nilai multikultural ini dapat diwujudkan dimana saja dan kapan saja, di rumah, di sekolah maupun di masyarakat. Pesantren merupakan lembaga pendidikan yang sudah menerapkan nilai-nilai multikultural dalam kesehariannya, baik pengelolanya maupun para santrinya yaitu dalam kegiatan penerimaan santri baru, pembagian kamar, penyelenggaraan forum diskusi santri dan keterlibatan para santri dalam event-event yang diadakan oleh pesantren. Keteladanan dari pengasuh pesantren terutama dari kiai sebagai figur sentral, menjadi satu strategi yang efektif dalam menanamkan nilai-nilai multukiultural. Pola keteladanan ini dikategorikan dalam tiga macam: 1) keteladanan kognitif, 2) keteladanan afektif, dan 3) keteladanan psikomotorik.

\section{DAFTAR PUSTAKA}

Azyumardi, A. (2001). Pendidikan Islam; Tradisional dan Modern Memuju Milenium Baru. Bandung: Mizan.

Dhofier, Z. (2011). Tradisi pesantren studi tentang pandangan hidup kiai dan visinya mengenai masa depan indonesia. Cet. Ke 9 , Jakarta: LP3ES.

Fakih, I. (2017). Kepemimpinan Pendidikan Multikultural (Tantangan Dan Solusinya). Transformasi: Jurnal Studi Agama Islam, 10(1), 1-17. http://ejournal.stainupacitan.ac.id/index.php/Transformasi/article/view $/ 1$

Fauzi, A. (2017). Persepsi Barokah di Pondok Pesantren Zainul Hasan Genggong Perspektif Interaksionalisme Simbolik. Al-Tahrir, 17(1), 105-132. 
Iswandi, I. (2019). Efektifitas Pendekatan Keteladanan Dalam Pembinaan Akhlak Siswa Di Min Bandar Gadang. Al-Tadzkiyyah: Jurnal Pendidikan Islam, 10(1), 113-136. https://doi.org/10.24042/atjpi.v10i1.3742

Mukhtar. (2013). Metode Praktis Penelitian Deskriptif Kualitatif. Jakarta: GP Press Group.

Rosita, N. (2018). Kepemimpinan Kharismatik Kiai di Pondok Pesantren Ali Maksum Krapyak Yogyakarta. SANGKéP: Jurnal Kajian Sosial Keagamaan, 1(2), 166-183. https://doi.org/10.20414/sangkep.v1i2.620

Shihab, M. Q. (2005). Tafsir Al-Mishbah: Pesan, Kesan dan Keserasian Al-Qur 'an. Cet III. Tangerang: Lentera Hati.

Suheri, \& Nurrahmawati, Y. T. (2018). Model Pendidikan Multikultural di Pondok Pesantren. Al-Insyiroh: Jurnal Studi Keislaman, 05(1), 32-48.

Sujarweni, V. W. (2014). Metodologi Penelitian. Yogyakarta: PT. Pustaka Baru.

Yusuf, A. (2019). Strategi Pembentukan Karakter Inklusif-Pluralis Melalui Keteladanan Multikultural Kiai Di Pesantren Ngalah Pasuruan. Pendidikan Multikultural, 3(1), 1. https://doi.org/10.33474/multikultural.v3i1.2549

Zamani, N. dan I. I. I. (2019). Implementasi Nilai-Nilai Multikultural di Pesantren Tebuireng. Al-Misbah, 7(1). 
